\title{
Çok işlevli proteinler: Moonlight proteinler
}

\section{Multifunctional Proteins: Moonlight Proteins}

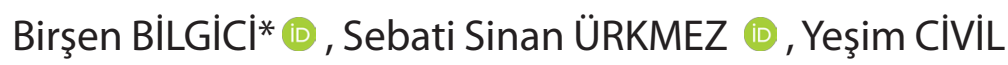

Ondokuz Mayıs Üniversitesi Tıp Fakültesi Tıbbi Biyokimya Anabilim Dalı, Samsun/TÜRKiYE

\begin{abstract}
Öz
Son yıllarda birçok proteinin birden fazla fonksiyona sahip olduğu bilgisi, bir gen - bir protein - bir fonksiyon fikrinin yerini almaya başlamıştır. Moonlight proteinler çok fonksiyonlu proteinlerin bir alt sınıfıdır. Moonlight protein kavramı, tek bir polipeptid zincirinin çoklu biyokimyasal fonksiyonları yerine getirmesini tanımlamaktadır. Bugün 300'den fazla moonlight proteini tanımlanmıştır. Bununla birlikte, veriler daha fazla moonlight proteini olabileceğini göstermektedir. Moonlight proteinlerin bilinen örnekleri arasında, reseptörler, enzimler, transkripsiyon faktörleri, adezinler ve hücre iskeleti de dahil olmak üzere çeşitli protein türleri bulunmaktadır. Bir moonlight protein, farklı hücre tiplerinde, farklı hücre içi lokasyonlarda, farklı oligomerik durumlarda bulunarak veya bir ligandın, substratın, kofaktörün ya da ürünün konsantrasyonundaki değişikliklere bağlı olarak ikinci fonksiyonunu aktifleştirebilmektedir. Ancak bu mekanizmalar, özgül değildir ve fonksiyonlar arasındaki geçişlerde bu yollardan birini ya da bunların bir kombinasyonunu kullanabilmektedir. Moonlight proteinlerin, nörodejeneratif hastalıklar ve kanser gibi hastalık fenotipleri ile ilişkili olabileceği öne sürülmektedir. Bunun yanısıra hastalık patogenezlerinde yer alarak tedavi süreçlerine bir takım zorluklar getirmekle birlikte potansiyel bir tedavi hedefi ve tedavi aracı olarak da fırsatlar sunmaktadır. Biz bu derlemede, başlıca insanlardaki mevcut moonlight proteinlerin biyokimyasal, fizyolojik ve patolojik özelliklerini ve hastalıklarla ilişkilerini tartışarak mevcut temel ve biyokimyasal bilgilerimize katkıda bulunmayı amaçladık.
\end{abstract}

Anahtar kelimeler : Moonlight proteinler; çok işlevli proteinler; protein fonksiyonu; metabolik düzenlenme; ilave yeni fonksiyonlar

Sorumlu yazar*: Birşen Bilgici , Ondokuz Mayıs Üniversitesi Tıp Fakültesi Tıbbi Biyokimya Anabilim Dalı, Samsun/TÜRKiYE E-posta: b_bilgici@yahoo.com

ORCID: 0000-0001-7783-5039

Gönderim: 20-03-2019 Kabul: 08-01-2020

Doi:10.18663/tjcl.542346 


\begin{abstract}
Aim: In recent years, the knowledge that many proteins have more than one function has begun to take the place of one gene - one protein - one function idea. Moonlight proteins are a subclass of multi-functional proteins. The concept of moonlight protein describes the ability of a single polypeptide chain to carry through multiple biochemical functions. Today more than 300 moonlight proteins have been identified. However, the data indicate that there may be more moonlight proteins. Known examples of moonlight proteins include a variety of protein types including receptors, enzymes, transcription factors, adhesins, and scaffold proteins. A moonlight protein can activate the second function in different cell types, at different intracellular locations, at different oligomeric states, or depending on changes in concentration of a ligand, substrate, cofactor or a reaction product. However, these mechanisms are non-specific and the mechanism of transition between functions may use one of them or their combination. Moonlight proteins have been suggested to be associated with disease phenotypes such as neurodegenerative diseases and cancer. Moonlight proteins bring some difficulties to treatment processes by taking place in pathogenesis of diseases but also offer opportunities as a potential treatment target and treatment tool. In this review, we aimed to contribute to our current basic and biochemical knowledge by discussing the biochemical, physiological and pathological features of the present moonlight proteins and their relationships with diseases.
\end{abstract}

Key words: Moonlight proteins; multifunctional proteins; protein function; metabolic coordination; additional novel functions

\section{Giriş}

Proteinler canlı organizmasında çok fazla çeşitlilikte fonksiyona sahip makromoleküllerdir. İnsan genom dizisinin anlaşılmasıyla, birçok farklı hücre tipine sahip böyle bir kompleks organizma için beklenenden çok daha az proteinin kodlandığı (19000 gen) ortaya çıkmıştır $[1,2,3]$. Çoğu proteinin tek bir fonksiyonu olmasına rağmen bazı proteinler multifonksiyoneldir ve her geçen gün bunlara yenileri eklenmektedir, dolayısıyla günümüzde "bir protein - birden fazla fonksiyon" fikri "bir gen - bir protein bir fonksiyon" hipotezinin yerini almaya başlamıştır $[2,3,4]$. Bu çok fonksiyonlu protein tiplerinden biri de moonlight proteinlerdir. Bu derlemede, başlıca insanlardan izole edilen moonligth proteinlere odaklanılmakla birlikte, örnek çeşitliliğini arttırmak amacıyla diğer türlerden de örnekler verilmiştir.

Moonlight tanımı, tek bir polipeptid zinciri tarafından iki veya daha fazla farklı fonksiyonu gerçekleştiren proteinlere karşılık gelmektedir [5]. İlk olarak 1980'lerin sonlarında Wistow ve Piatigorsky tarafından lens kristalinlerinin, metabolik enzim fonksiyonlarının gösterilmesiyle keşfedilmiştir $[7,6]$. Başlangıçta Piatigorsky bu proteinleri "gen paylaşımı" proteinleri olarak adlandırmış daha sonra Constance Jeffery tarafından 1999 'da "moonlight" tanımı gündüz ve gece farklı işler yapan insanlara benzerlik oluşturmak için kullanılmış ve kabul görmüştür $[5,8]$.
Moonlight fonksiyonlar, gen füzyonlarını, ribonükleik asit (RNA) splicing varyantlarını, homolog protein ailelerini veya multipl proteolitik fragmentlere bağlı ek fonksiyonları kapsamamaktadır. Ayrıca geniş substrat spektrumuna sahip detoksifikasyon enzimleri, anormal koşullarda (örneğin; fizyolojik olmayan bir substratın yüksek konstrasyonu) farklı reaksiyonları katalizleyen karmaşık fonksiyonlu enzimler, bir biyokimyasal fonksiyonla sonuçlanan farklı yollarda veya fizyolojik süreçlerde birden fazla hücresel yolakta farklı fonksiyonlara sahip pleiotropik proteinler ve farklı hücre tiplerinde veya hücre altı lokasyonlarda aynı işleve sahip proteinler, moonlight protein kapsamında değildirler $[4,9,10,11]$.

Moonlight proteinlerin çoklu fonksiyonları birbiriyle bazı durumlarda tamamen ilgisiz bazı durumlarda ise bağlantılı olabilir. Bu durum beraberinde organizmaya bir dizi faydalar getirmektedir. Moonlight proteinler, birbiriyle ilişkili hücresel aktivitelerin koordinasyonuna aracı olabilmektedir [9]. Kistik fibrozis transmembran iletkenlik düzenleyici (CFTR) protein, hem siklik adenozin monofosfata (CAMP) bağlı bir klorür kanalı hem de bir epitelyal sodyum kanalı $(E N a C)$ düzenleyicisidir. CFTR'nin defektif olması mukoza epitel hücresinde $\mathrm{Cl}^{-}$retansiyonu ve aşırı $\mathrm{Na}^{+}$absorbsiyonu ile sonuçlanır ki bu durum proteinin bifonksiyonel karakteriyle ilgilidir [12]. 1-cys peroksiredoksin, iki farklı aktif bölgede fosfolipaz A2 ve 
glutatyon peroksidaz aktiviteleri gösteren bifonksiyonel bir enzimdir ve bu iki fonksiyonun oksidatif strese karşı birlikte hareket ettiği düşünülmektedir [13]. Trombin, koagulasyon kaskadında hem fibrinojeni fibrine çeviren bir proteaz hem de G-protein ilişkili proteaz aktive edici reseptör-1 (PAR-1) aktivasyonuyla trombosit adezyonuna neden olan bir sinyal proteinidir [14]. Siklin bağımlı kinaz 1 (CDK1) hücre siklusunun geç G2 ve mitoz fazlarını kontrol eden bir serin/treonin kinazdır. Anafaz uyarıcı kompleks/ siklozom (APC/C) ise CDK1 ile kompleks oluşturarak mitotik sürecin sonlanmasını kontrol eden bir düzenleyici proteindir. CDK1-APC/C kompleksinin siliyalı hücrelerde mitoz bölünmeden sonra sentriollerin üretimini, gelişimini ve siliyer yapılara farklılaşmasını sağladığı bulunmuştur [15]. Bir proteinin iki tamamlayıcı fonksiyona sahip olması, farklı yolaklar arasında bir geçiş görevi görebileceğini de düşündürmektedir [9]. Örneğin, ökaryotik mitokondride, Lon ATP'ye bağımlı bir proteazdır fakat aynı zamanda da bir şaperondur [16].

Moonlight kavramı sıklıkla proteinleri belirtmek için kullanılmakla birlikte güncel bir çalışmada çinko parmak $(\mathrm{ZnF})$ motif içeren bir protein ailesi olan Cys2His2 (C2H2)ZNF'ye ait mRNA'ların da sıra dışı bir özelliği keşfedilmiştir. Bu mRNA'lar üzerindeki çinko parmak motiflerinindeki tekrarlı sekansların, mRNA'nın poliadenilasyon sürecini kısıtladığı ve bundan bağımsız olarak mRNA'nın nükleustan sitozole translokasyonunu inhibe ettiği tespit edilmiştir [17]. Bu durum ihtiyaç halinde kullanılmak üzere bu mRNA'ların depolanabileceğini düşündürmekle birlikte moonlight kavramının kapsamını transkript düzeyine genişletme potansiyelini de taşımaktadır.

\section{Moonlight Proteinlerin Evrimi}

Gancedo ve Flores, "evrimde nihai bir amaç olmadığı ve yeni işlevlerin sadece var olanları uyarlayarak geliştiği" teorisinden yola çıkarak belirli bir yeni fonksiyonun, evrim sırasında seçilmesinin ancak organizma için avantaj sağladığında olası olduğunu belirtmişlerdir [18]. Bununla birlikte, çoklu rolleri olan proteinlerin neden evrimleştiğini açıklayan evrensel olarak kabul edilmiş bir teori yoktur $[5,19]$. Moonlight proteinlerin, tek fonksiyona sahip çok sayıda proteinin sentezlenmesi için gereken amino asitleri ve enerjiyi muhafaza ederek evrimsel açıdan organizma için avantajlı bir durum yarattığı düşünülmektedir [5]. Bazı moonligth proteinlerin ise, herhangi bir sitozolik proteinin medyan uzunluğundan daha uzun ve buna bağlı olarak daha kararlı bir yapıda oldukları bulunmuştur. Bu durum hücre sitozolünden daha zorlu bir ortamda yeni bir fonksiyon için gerekli kararlılığa nasıl sahip olduklarını ve moonlight fonksiyonu için seçilme nedenlerini açıklarken, proteinin esas işlevini etkilemeden, küçük bir yüzey bölgesinin yeni bir protein bağlama bölgesi oluşturmak için evrimsel modifikasyona uğrama olasılığını yaratmaktadır [20].

\section{Moonlight Protein Örnekleri ve Fonksiyonlar Arası Geçiş Mekanizmaları}

Moonlight proteinler birçok organizmada yaygın bir şekilde bulunmaktadır ve bugüne kadar 300'den fazla moonlight proteini tanımlanmıştır [21]. Bununla birlikte, veriler daha fazla moonlight proteini olabileceğini göstermektedir [20]. Moonlight proteinlerin bilinen örnekleri arasında, reseptörler, enzimler, transkripsiyon faktörleri, adezinler ve hücre iskelet proteinleri gibi çeşitli protein türleri bulunmaktadır [4,5,22]. Glikolitik yoldaki 10 enzimin 7'sinin ve trikarboksilik asit (TCA) döngüsündeki 8 enzimin 7'sinin de moonlight fonksiyonuna sahip olduğu bildirilmiştir $[23,24]$. Tompa ve ark., bazı moonlight proteinlerin, aslında düzensiz proteinler (IUP) olarak bilinen, iyi tanımlanmış üç boyutlu bir yapıya sahip olmayan proteinler olabileceğini ileri sürmüşlerdir (Örnek: p53proteini) [25], ancak bu görüşe fazla ilgi gösterilmemiştir [26]. Tanımlanmış bazı insan moonligth proteinleri Tablo 1 'de verilmiştir.

Bazı moonlight proteinler, her iki işlevi aynı anda yerine getirebilirken bazıları moonlight fonksiyonlarını, hücre içinde meydana gelen değişikliklere bağlı olarak gerçekleştirir. Bir moonlight protein, farklı hücre tiplerinde, farklı hücre içi lokasyonlarda, farklı oligomerik durumlarda bulunarak veya bir ligandın, substratın, kofaktörün ya da bir reaksiyon ürünün konsantrasyonundaki değişikliklere bağlı olarak ikinci fonksiyonunu aktifleştirebilir [27,28]. Bu mekanizmalar, özgül değildir, bir proteinin fonksiyonları arasındaki geçişte bunlardan biri ya da bunların bir kombinasyonu kullanılabilir [5]. 
BíLGiCi ve ark.

Tablo 1. Insanlarda tanımlanan bazı moonlight proteinler

Protein 1. Fonksiyon

1-Sistein Peroksiredoksin

Asidik kalsiyumdan bağımsız fosfolipaz A2 (aiPLA2)

2. Fonksiyon

Isı şok proteini $60(\mathrm{Hsp} 60)$

Proteinlerin mitokondri dışına transportu, doğru ve yeniden katlanmanın uyarılması, yanlış katlanmanın önlenmesi

Selenyum içermeyen glutatyon peroksidaz

Enolaz

Enolaz

Laktoz sentaz

Delta-aminolevulinik asit dehidrataz

Lökotrien A4 hidrolaz

Lizil hidroksilaz

Fosfogliserat kinaz

Timozin beta-4

Timidin fosforilaz

\section{Kalretikülin}

Gliseraldehid-3-fosfat dehidrogenaz

Ribozomal protein S7, L11, L5, L23

Timidilat sentaz

Dihidrofolat redüktaz

Akonitaz

Band 3 anyon değiştirici

Kistik fibrozis transmembran iletkenlik düzenleyici (CFTR)

Çoklu ilaç direnci protein 1 (MDR)

Aldolaz

Enolaz, glikoliz enzimi

Laktoz sentaz, enzim

5-aminolevulinat dehidrataz, enzim

Lökotrien A-4 hidrolaz, enzim

Lizil hidroksilaz izoform 3, enzim

Fosfogliserat kinaz, glikoliz enzim

Polimorfonükleer lökositlerinde G-aktin sekestrasyonu

Pirimidin metabolizması, kurtarma yolunda dTMP biyosentezi

Şaperon

Glikoliz enzimi

Ribozomun 40S (S7) ve 60S (L11, L5, L23) alt birimi bileşenleri

Pirimidin metabolizması de novo timidilat sentezi

Tetrahidrofolat biyosentezi enzimi

Sitrik asit döngüsü enzimi

Plazma membranı boyunca inorganik anyonların taşınması

Klorid taşıyıcı; Adenozin trifosfat (ATP) bağlayan ve hidrolize eden nükleotid bağlayıcı alanlar içerir.

ATP bağımlı transmembran taşıyıcı; ilaçlar ve diğer küçük moleküllü bileşikler

Glikoliz, enzimi

Endositozda klatrin kaplı çukur oluşumu ve klatrin ve adaptör protein kompleksi 2'yi hücre zarına taşıma

Fosfatidilinositol bağlayıcı klatrin montaj proteini

Metilglutakonil-Koenzim A hidrataz

Lösin katabolizmasında enzim

Fruktoz-1,6-bisfosfataz

Glukoneogenez enzimi

Glutatyon S-transferaz M3

Glutatyon S-transferaz enzim

Glikoliz enzimi

Fosfogliserat kinaz 1

Fosfogliserat kinaz, enzim

Glutatyon peroksidaz 4

Fosfolipit hidroperoksit glutatyon peroksidaz

Piruvat kinaz izozim M2

Piruvat kinaz, glikoliz enzimi

Triozfosfat izomeraz, enzim
Yüksek dansiteli lipoprotein

(HDL) için apolipoprotein apo A-II reseptörü

Plazminojen bağlama

Galaktoziltransferaz, enzim

Proteozom inhibitörü

Aminopeptidaz, enzim

Kollajen glukoziltransferaz, enzim

Disülfit redüktaz, enzim

Salgılanabilen anti-inflamatuar ajan

Trombosit kaynaklı endotel hücre büyüme faktörü

Adezin

Interferon-gamma (IFN- $\gamma$ ) ile aktive translasyon inhibitörü (GAIT) kompleksi bileşeni

Ubikitin ligaz inhibisyonu

Kendi mRNA translasyonunun inhibisyonu

Kendi mRNA'sına bağlanarak sentezini düzenler

Demir duyarlı element bağlayıcı protein (IRE-BP)

Glikolitik enzimlerin katalitik aktivitesinin düzenlenmesi

Bazı iyon kanallarının düzenlenmesi

Hacim ile aktive klorür kanallarının düzenlenmesi

Ovumun zona pellusida proteinleri ile etkileşim

Transkripsiyon aktivasyonu

\section{RNA bağlama}

Hipoksi indüklenebilir faktör (HIF) proteinine bağlanır ve inhibe eder

Spermatozoan üzerinde bulunur ve rekombinant insan zona pellusida protein 4 (rhZP4) ile etkileşime girer

Transkripsiyon faktörleriyle etkileşim

mRNA'yı bağlayarak ürokinaz reseptörünün ekspresyonunu düzenler

Zona pellusida proteinleri ile etkileşim

Transkripsiyon düzenleyicisi

Zona pellusida proteinleri (rhZP3 ve rhZP4) ile etkileşim

*Tablodaki veriler MOONPROT veri bankasından (http://moonlightingproteins.org/) elde edilmiştir [21]. 


\section{Bazı proteinler hücre içinde ve dışında farklı fonksiyona sahiptirler}

Hücre sitozolünde fosfoglukoz izomeraz (PGI) bir glikoliz enzimidir ve birçok hücre tarafından ekstrasellüler ortama salgılanabilir ve en az dört ek fonksiyona sahiptir [5]. PGI ile amino asit dizilimi \% 90 homoloji gösteren nörolokin (NLK) lektin ile stimule edilmiş $\mathrm{T}$ hücreleri tarafından salınan bir lenfokindir, ayrıca spinal ve sensorik nöronlar için nörotrofik etkiye sahiptir [29,30,31]. PGı ile aynı protein olduğu sekans analizi ile belirlenen otokrin motilite faktörü (AMF) in vitro hücre göçünü ve in vivo metastazı uyaran, kanser hücrelerinden salgılanan bir sitokindir [32]. Insan myeloid lösemi hücrelerden salınan farklılaşma ve matürasyon mediatörü (DMM) amino asit sekansının PGI ve NLK ile \%100 homoloji gösterdiği bulunmuştur [33].

Matriks metalloproteinazları (MMP), ekstrasellüler matriks ile bazal membran komponentlerini parçalayarak matriksin protein turnoverını sürdüren homolog bir enzim ailesidir. Hücre içinde farklı substratlar üzerinde proteolitik etkiye sahip olmakla birlikte aynı zamanda bir transkripsiyon faktörü, sinyal molekülü ve bakterisidal etkili proteinlerdir [34].

Timidin fosforilaz ile trombositten türetilmiş endotelyal hücre büyüme faktörü (PD-ECGF) 120 aminoasitlik aynı sekansa sahiptir. Hücre sitozolünde timidin fosforilaz, timidin ve deoksiüridini geri dönüşümlü olarak desfosforile ederek bunları kendilerine özgül bazlara ve 2-deoksiriboz 1-fosfata ayrılmasını katalize ederken, PD-ECGF endotelyal hücre gelişimini, kemotaksisi ve anjiyogenezi ekstrasellüler olarak uyarır [35].

\section{Bazı proteinler ekpresyon bölgelerine göre farklı fonksiyona sahiptirler}

Moonlight proteinler, eksprese edildikleri hücre türüne göre farklı fonksiyonlar gösterebilmektedir [36]. Nöropilin, endotelyal hücrelerde eksprese edildiğinde, vasküler endotelyal büyüme faktörünü tanıyan ve anjiyogenezi uyaran bir hücre yüzey reseptörüdür. Aynı protein nöronlarda eksprese edildiğinde ise kollapsin/semaforini tanıyan ve aksonları uygun lokalizasyonlara yönlendiren bir hücre yüzey reseptörüdür [37].

\section{Bazı proteinler, monomerik ve multimerik formlarda farklı} fonksiyonlara sahiptir

Gliseraldehit-3-fosfat dehidrogenaz, tetramer yapıda glikolitik yoldaki enzim fonksiyonunu gösterirken monomer yapıda, nükleer urasil-DNA glikozilaz fonksiyonunu göstermektedir [38]. Piruvat kinaz da yine tetramer yapıda glikolitik yoldaki metabolik aktivitesini gösterirken monomerik yapıda ise tiroid hormon bağlayıcı protein fonksiyonunu gösterir [39].

\section{Bir enzimin fonksiyonu, mevcut substrat, ligand veya kofaktör miktarı ile değişebilmektedir}

Akonitaz, yüksek hücresel demir konsantrasyonlarında sitrik asit siklusunda yer alan demir bağımlı bir enzimdir. Hücresel demir konsantrasyonu azaldığında, üzerindeki Fe-S kümesini dolayısıyla akonitaz aktivitesini kaybetmekte ve demir yanıt elementi bağlayıcı protein (IRE-BP) rolünü üstlenmektedir [40]. Bu durumda demir yanıt elementine (IRE) bağlanan IRPBP transferrinin mRNA translasyonunu artırırken, ferritinin mRNA translasyonunu inhibe ederek demir konsantrasyonu artırılmaya çalışılır.

\section{Bağlanma bölgeleri ikinci fonksiyona sahip olabilir}

Bazı moonlight enzimler, farklı bağlanma bölgeleri kullanarak çoklu işlevlerini yerine getirebilmektedirler [10]. Enolaz glikoliz yolağında yer alan ubikitöz bir enzimdir. Aynı zamanda hücre dışında plazminojeni bağlama fonksiyonu göstermektedir. Plazminojen bağlayan bölgenin enolazın katalitik aktif bölgesinden farklı, molekülün C-terminalinde genellikle lizin içeren kısa bir amino asit sekansı olduğu bulunmuştur [41]. Eya proteinleri (Eyes Absent proteins) six homeoprotein (Sineoculis homeobox) ailesinin başlıca transkripsiyonel ko-aktivatörleridir ve organogenezde önemli rolleri vardır. Buna ek olarak bu proteinler, C-terminalinde iki farklı bölgede, $\mathrm{Mg}^{2+}$ bağımlı tirozin fosfataz aktivitesine sahiptir [42]. Bununla birlikte bazı proteinler için mevcut aktif bölgenin kullanıldığı durumlar da vardır. Örneğin IRE-BP'nin RNA-bağlama bölgesinin akonitazın aktif bölgesinde yer aldığı gösterilmiştir [43].

\section{Post translasyonel modifikasyonlar çoklu fonksiyon sağlayabilir}

Çok fonksiyonellik, post translasyonel modifikasyonların bir sonucu olarak da ortaya çıkabilmektedir [44]. Bazı hücre yüzey proteinlerinde birkaç yüzey amino asidinin veya $C$ terminal kalıntısının lizinler ile yer değiştirmesiyle, genel protein yapısında veya orijinal işlevinde önemli değişikliklere neden olmaksızın plazminojen için bağlanma bölgeleri oluştuğu gösterilmiştir [20]. Ayrıca fosforilasyon da moonlight protein fonksiyonuna geçişe neden olabilmektedir. Örneğin, fosfoglukoz izomerazın Ser-185 kalıntısından fosforilasyonu, glikolitik enzim fonksiyonunu durdururken, proteinin otokrin motilite faktörü fonksiyonu devam eder [45]. Buna ek olarak GAPDH'ın fosforilasyon, nitrozilasyon, asetilasyon gibi posttranslasyonel modifikasyonları proteinin farklı fonksiyonları ile ilişkilidir [46]. 


\section{Hastalıkların Patofizyolojisinde ve Tedavisinde Moonlight} Proteinlerin Yeri

Bazı hastalıkların moonlight proteinler ile ilişkili olabileceğini gösteren veriler bulunmaktadır. Konformasyonu değişen proteinlerin yeni yapılara bağlanarak çeşitli patolojilere sebep olması bir moonlight olgusudur [47]. Trioz fosfat izomeraz (TPI) enzimindeki bazı mutasyonlar, yeni protein-protein etkileşimlerine yol açarak aneminin ve hatta şiddetli nörolojik hastalıkların ortaya çıkmasına sebep olabilmektedir. Oluşan TPI agregatları düzensiz yapıdadır ve diğer hücresel proteinlerin de birikmesine yol açabilmektedir [48]. GAPDH'ın, $\beta$-amiloid öncü proteini, huntingtin ve $a$-sinüklein gibi nörodejeneratif hastalıklarda ( Alzheimer, Huntington, Parkinson hastalıkları) rol oynayan proteinlere bağlandığı gösterilmiştir [49]. Bu yeni bağlanma modelinde, protein birikiminin yansıra, hücre içi enerji metabolizmasının yavaşlamasına da neden olarak nörodejenerasyona katkıda bulunulabileceği ileri sürülmüştür [50]. Senil sistemik amiloidoz ve ailesel amiloid polinöropatisinde de transtiretinin konformasyonunun değişmesi, amiloid fibrillerinin oluşumuna yol açarak, nörodejenerasyon patogenezinde önemli bir rol oynadığı rapor edilmiştir $[51,52]$.

Moonlight proteinler anormal enzimatik özellikler göstererek de bazı patolojilere yol açabilirler. Dihidrolipoamid dehidrogenaz (DLD), çeşitli çoklu enzim komplekslerinde bulunan flavin bağımlı, homodimerik bir oksidoredüktazdır. DLD aktivitesi, hücrede enerji ve redoks dengesi için kritik öneme sahiptir ve aktivite eksikliğinde infantlarda büyüme ve gelişme hızının yavaşlaması, hipotoni ve metabolik asidozla karakterize şiddeti değişen derecelerde patolojilere yol açmaktadır. Homodimer yapısı bozulduğunda DLD monomerleri enerji metabolizmasındaki görevlerini yerine getiremezken ayrıca bu monomerler moonlight fonksiyon kazanarak proteaz aktivitesi ile mitokondriyal proteinleri yıkıma uğratmaktadır [53].

Moonlight proteinler kanserle ilişkili bazı hücresel ve biyokimyasal yolaklarda da yer alır [9]. Ribozom alt birimlerine ait bir çok yapısal protein, aynı zamanda çeşitli kanser tiplerinin oluşumunda ve progresyonunda önemli görevleri olan birer sinyal molekülü ve/veya transkripsiyon faktörüdür. Söz konusu bu etkiler hem onkojenik hem de tümör supresör özelikte olabilmektedir [54]. Isı şok proteini 90 (Hsp90), proteinlerin ATP aracılı katlanmasına, kararlılığına, proteolitik döngüsüne aracılık eden sitoplazmik bir şaperondur [55]. Bununla birlikte, Hsp90 hem salgılanabilen bir protein hem de membran yüzey proteinidir. Ekstrasellüler Hsp90'nın salgılanabilen formu proonkojenik bir protein olarak kabul edilmektedir [56].
Salgılanmış Hsp90, anjiyogenez ve kanser hücresi invazyonuna katkıda bulunan matriks metalloproteinaz-2'yi (MMP-2) kararlı hale getirir [57]. Ayrıca bu formun prostat kanserinde E-kaderin fonksiyonunu değiştirdiği ve epitelyal-mezenkimal transformasyona yol açtığı da bildirilmiştir [58].

Glikolitik yola ait a-enolazın artmış ekspresyonunun, nöroblastoma ve akciğer kanserinde tümör gelişimi ile korelasyonu bildirilirken, bir çok tümörün potansiyel tanısal belirleyicisi olduğu düşünülmektedir. Tümörlerin dışında a-enolazın değişmiş ekpresyonlarının Alzheimer, reumatoid artrit gibi diğer hastalıklarla da ilişkili olduğu rapor edilmiştir [59]. Kanserle ilişkili bazı proteinler Tablo 2 'de özetlenmiştir.

\begin{tabular}{|c|c|c|}
\hline Protein & Primer Fonksiyon & Ek Fonksiyon \\
\hline $\begin{array}{l}\text { Transglutami- } \\
\text { naz } 2 \text { (TG2) }\end{array}$ & $\begin{array}{l}\text { Sitoplazma; Protein } \\
\text { çapraz bağlarının } \\
\text { oluşumunun katalizi }\end{array}$ & $\begin{array}{l}\text { Nükleus; Pro-tümöral gen } \\
\text { ekspresyonunu düzenler } \\
\text { Ekstrasellüler bölge; Hücre } \\
\text { adezyonu }\end{array}$ \\
\hline GAPDH & $\begin{array}{l}\text { Sitoplazma; Glikolitik } \\
\text { enzim }\end{array}$ & $\begin{array}{l}\text { Nükleus; p53 gen düzen- } \\
\text { lenmesine ve apoptotik } \\
\text { yolakların aktivasyonuna } \\
\text { katılır, bunun yanında } \\
\text { hücre farklılaşmasını da } \\
\text { uyararak pro-tümöral etki } \\
\text { gösterebilir }\end{array}$ \\
\hline p53 & $\begin{array}{l}\text { Nükleus; Transkripsi- } \\
\text { yon faktörü }\end{array}$ & $\begin{array}{l}\text { Mitokondri; Mitokondriyal } \\
\text { membran geçirgenliğinin } \\
\text { arttırılması } \\
\text { Nükleus; DNA onarımı ve } \\
\text { apopitoz }\end{array}$ \\
\hline $\begin{array}{l}\text { Yüksek mobi- } \\
\text { liteli grup B1 } \\
\text { (HMGB1) }\end{array}$ & $\begin{array}{l}\text { Nükleus; Nükleo- } \\
\text { zomlara bağlanarak } \\
\text { transkripsiyon } \\
\text { faktörlerinin } \\
\text { etkileşimini düzenler }\end{array}$ & $\begin{array}{l}\text { Ekstrasellüler bölge; } \\
\text { inflamatuvar sitokin }\end{array}$ \\
\hline$\beta$-katenin & $\begin{array}{l}\text { Nükleus: Wnt genleri } \\
\text { için transkripsiyon } \\
\text { faktörü }\end{array}$ & $\begin{array}{l}\text { Sitoplazma; diğer katenin- } \\
\text { ler ve aktinler ile etkileşim }\end{array}$ \\
\hline $\begin{array}{l}\text { Non-steroid } \\
\text { anti-inflamat- } \\
\text { uar ilaç aktive } \\
\text { gen (NAG-1) }\end{array}$ & $\begin{array}{l}\text { Ekstrasellüler bölge: } \\
\text { Hücre büyümes- } \\
\text { inin inhibisyonu, } \\
\text { apopitozun ise } \\
\text { uyarılması }\end{array}$ & $\begin{array}{l}\text { Nükleus: Invazyona, } \\
\text { metastaza, EMT, plasmi- } \\
\text { nojen aktivatör inhibi- } \\
\text { tor-1 (PAI-1) ve MMP'lerin } \\
\text { salınımına yönelik pro- } \\
\text { tümöral gen ekspresyo- } \\
\text { nunu düzenleme }\end{array}$ \\
\hline MMP'ler & $\begin{array}{l}\text { Ekstrasellüler } \\
\text { bölge; proteoliz ve } \\
\text { büyüme faktörü } \\
\text { aktivasyonu veya } \\
\text { serbestleştirilmesi }\end{array}$ & $\begin{array}{l}\text { Nükleus: Konektif doku } \\
\text { büyüme faktörü (CTGF) ve } \\
\text { NF-kB gibi genlerin ekspr- } \\
\text { esyonunu düzenler }\end{array}$ \\
\hline E-kaderin & $\begin{array}{l}\text { Hücre yüzeyi: hücre } \\
\text { adezyonuna ve } \\
\text { kontakt inhibisyona } \\
\text { katılır }\end{array}$ & $\begin{array}{l}\text { Nükleus: C-terminal frag- } \\
\text { ment-2 (CTF2) ile etkileşim } \\
\text { sonucu apopitozun inhi- } \\
\text { bisyonu }\end{array}$ \\
\hline \multicolumn{3}{|c|}{$\begin{array}{l}\text { * Bu tablo Kyung-Won M. ve ark'ın "Moonlighting proteins in cancer } \\
\text { (2016)" adlı mini derlemesinden alınarak tekrar düzenlemiştir [56]. }\end{array}$} \\
\hline
\end{tabular}


Birden fazla fonksiyonu olan bir moonlight proteinin hastalık halinde bu fonksiyonlarından hangisi ve/veya hangilerinin etkilendiği bir belirsizlik yaratmakta ve sadece tek bir fonksiyonuna yönelik tedavi yeterli olamayabilmektedir [9]. Bazı durumlarda ise moonlight proteininin sadece tek bir fonksiyonunu engellemek gereklidir [4]. Örneğin, Six homeoproteinlerin transkripsiyon koaktivatörü olan Eya proteinleri aynı zamanda Tyr fosfataz aktivitesine sahiptir. Söz konusu bu fosfataz aktivitesinin hedefleri H2AX ve ERp proteinleridir ve bu proteinlerin defosforilasyonu sırasıyla DNA hasarı durumunda hücreyi apoptotik yol yerine DNA onarımına yönlendirmekte ve anti-tümöral transkripsiyonel aktivenin inhibisyonuna neden olmaktadır. Dolayısıyla Eya proteinlerinin fosfataz aktivitesinin inhibisyonu kanser tedavisi için önem taşımaktadır [42]. Fosfoglikoz izomerazın otokrin motilite faktörü aktivitesi, motilite ve metastazın uyarılması, endotelyal hücrelerde anjiyogenezin uyarılması, apoptozun inhibisyonu gibi etkilere sahiptir dolayısı ile kemoterapi için iyi bir hedeftir. Ancak kemoterapotiklerin, fosfoglukozun enzim, nörolökin ve matürasyon faktörü gibi etkilerini engellememesi yaşamsal açıdan önemlidir [10].

Moonlight proteinler potansiyel tedavi hedefleri olmalarının yanında tedavi aracı da olabilir. Örneğin, Parkinson hastalığında bir monoamin oksidaz B inhibitörü olan deprenil kullanılmaktadır. Bir deprenil türevi olan TCH346, monoamin oksidazı etkin bir şekilde inhibe etmese de sahip olduğu nöroprotektif etki hastalığın tedavisine katkı sağlamaktadır [60]. Steril a motif ve histidin $(\mathrm{H})$ aspartat $(\mathrm{D})$ domain içeren protein 1 (SAMHD1), HIV-1 infeksiyonlarında kullanılan anti viral bir dNTP trifosfohidrolazdır. Yapılan bir çalışmada SAMHD1'in, DNA çift iplik kırılmalarının homolog rekombinasyonunu kolaylaştırdığı, dolayısıyla kanser tedavisinde fayda sağlayabileceği bildirilmiştir [61]. Öte yandan sitokin fonksiyonlu moonlight proteinler, bağışıklık sisteminin modülasyonu amacıyla kullanım alanı sunmaktadır. Örneğin, İnsan şaperon proteini Hsp10, immün supresif etkilere sahiptir ve multipl skleroz, romatoid artrit, ve psöriyazis tedavisi için rekombinant Hsp10'un güvenilirliği ve etkinliği değerlendirilmektedir [62,63,64].

Bazı proteinler moonlight özelliklerinden dolayı hastalık tanısında kullanılabilecek potansiyel belirteçler olabilir. RPL10 ribozomun 605 alt ünitesine ait bir yapısal proteindir. Ancak bu proteinin, karsinogenez sürecinde artan mitokondriyal ROS üretiminin nötralizasyonu ile ilgili proteinlerin ekspresyonunu düzenlenmesi ve elektron transfer zincirinde kompleks 1'i etkileyerek, ROS seviyelerinin düzenlenmesinde yer aldığı bildirilmiştir. Ayrıca RPL10'un pankreatik kanser olgularında tümorogenezin bir belirteci olabileceği ileri sürülmüştür [65].

\section{Moonlight Protein Veri Tabanları}

Protein Veri Bankasındaki proteinlerle karşılaştırıldığında, moonlight proteinleri kapsayan az sayıda veri vardır. Ancak moonlight proteinler için yeni veri tabanları oluşturulmaktadır. Şu anda, üç adet moonlight protein veri tabanı bulunmaktadır. Bunlardan birincisi, MultitaskProtDB (http://wallace.uab. es/multitaskll/) [66]. İkincisi olan MOONPROT (http:// moonlightingproteins.org), Jeffery laboratuarı tarafından derlenen bir veri tabanıdır [21]. Üçüncüsü MoonDB (http:// tagc.univ-mrs.fr/MoonDB/), literatürden elde edilen insan moonlight proteinlerini ve network tabanlı bir yaklaşımla moonlight protein adaylarını içermektedir [67]. Ayrıca moonlight protein-protein etkileşimleri, APID (Agile Protein Interactomes DataServer) sitesinde (http://cicblade.dep.usal. es:8080/APID/init.action) yer almaktadır [68].

\section{Sonuç}

Moonligth proteinler normal hücre çoğalması, farklılaşması ve biyokimyasal yollarda çevresel şartlara göre birden fazla fonksiyon üstlenerek metabolizmanın düzenlenmesinde rol alırken, birçok hastalık ve kanserin patogenezinde de rol oynadığından potansiyel tedavi hedefi olarak da umut vadetmektedir ve bu konuda daha fazla sayıda çalışmaya ihtiyaç vardır.

\section{Çıkar çatışması / finansal destek beyanı}

Bu yazıdaki hiçbir yazarın herhangi bir çıkar çatışması yoktur. Yazının herhangi bir finansal desteği yoktur.

\section{Kaynaklar}

1. Ezkurdia I, Juan D, Rodriguez J et al. Multiple evidence strands suggest that there may be as few as 19,000 human proteincoding genes. Hum Mol Genet 2014; 23: 5866-78.

2. O'Leary NA, Wright MW, Brister JR et al. Reference sequence (RefSeq) database at NCBI: current status, taxonomic expansion, and functional annotation. Nucleic Acids Res 2016; 44: 733-34.

3. Omenn GS, Lane L, Lundberg EK et al. Metrics for the human proteome project 2016: progress on identifying and characterizing the human proteome, including posttranslational modifications. J Proteome Res 2016; 15: 3951-60.

4. Jeffery CJ. Moonlighting proteins-an update. Mol BioSyst 2009; 5: 345-50.

5. Jeffery CJ. Moonlighting proteins. Trends Biochem Sci 1999; 24: 8-11.

6. Piatigorsky J and Wistow GJ. Enzyme/crystallins: gene sharing as an evolutionary strategy. Cell 1989; 57: 197-99.

7. Wistow $G$ and Piatigorsky J. Recruitment of enzymes as lens structural proteins. Science 1987; 236: 1554-56.

8. Cvekl A and Zheng D. Gene sharing and evolution. Hum Genomics 2009; 4: 66-67. 
9. Jeffery CJ. Multifunctional proteins: examples of gene sharing Ann Med 2003; 35: 28-35.

10. Copley SD. Moonlighting is mainstream: Paradigm adjustment required. Bioessays 2012; 34: 578-88.

11. Copley SD. Enzymes with extra talents: moonlighting functions and catalytic promiscuity. Curr Opin Chem Biol 2003; 7: 265-72.

12. Stutts MJ, Canessa CM, Olsen JC et al. CFTR as a cAMP-dependent regulator of sodium channels. Science 1995; 269: 847-50.

13. Chen JW, Dodia C, Feinstein SI, Jain MK, Fisher AB. 1-Cys peroxiredoxin, a bifunctional enzyme with glutathione peroxidase and phospholipase A2 activities. J Biol Chem 2000; 275: $28421-27$.

14. Vu TK, Hung DT, Wheaton VI, Coughlin SR. Molecular cloning of a functional thrombin receptor reveals a novel proteolytic mechanism of receptor activation. Cell 1991; 64: 1057-68.

15. Al Jord A, Shihavuddin A, Servignat d'Aout R et al. Calibrated mitotic oscillator drives motile ciliogenesis. Science 2017; 358: 803-06.

16. Suzukia CK, Rep M, van Dijl JB, Suda K, Grivell LA, Schatz G. ATPdependent proteases that also chaperone protein biogenesis. Trends Biochem Sci 1997; 22: 118-23.

17. Russo J, Jalkanen AL, Heck AM, Schmidt CM, Wilusz J, Wilusz CJ. Sequences encoding $\mathrm{C} 2 \mathrm{H} 2$ zinc fingers inhibit polyadenylation and mRNA export in human cells. Sci Rep 2018; 8: 16995.

18. Gancedo $C$ and Flores CL. Moonlighting proteins in yeasts. Microbiol Mol Biol Rev 2008; 72: 197-210.

19. Huberts $\mathrm{DH}$ and van der Klei IJ. Moonlighting proteins: an intriguing mode of multitasking. Biochim Biophys Acta 2010; 1803: 520-25.

20. Amblee V and Jeffery CJ. Physical Features of Intracellular Proteins that Moonlight on the Cell Surface. PLoS ONE 2015; 10: e0130575.

21. Chen C, Zabad S, Liu H, Wang W, Jeffery C. MoonProt 2.0: an expansion and update of the moonlighting proteins database. Nucleic Acids Res 2018; 46: 640-44.

22. Jeffery CJ. Moonlighting proteins: complications and implications for proteomics research. Drug Discov Today: Targets 2004; 3: 71-78.

23. Lu Z and Hunter T. Metabolic Kinases Moonlighting as Protein Kinases. Trends Biochem Sci 2018; 43: 301-310.

24. Kim JW and Dang CV. Multifaceted roles of glycolytic enzymes. Trends Biochem Sci 2005; 30: 142-50.

25. Tompa P, Szász C, Buday L. Structural disorder throws new light on moonlighting. Trends Biochem Sci 2005; 30: 484-89.
26. Hernández S, Amela I, Cedano J et al. Do moonlighting proteins belong to the intrinsic disordered proteins class? J J Proteomics Bioinform 2012; 5: 262-64.

27. Jeffery CJ. Molecular mechanisms for multitasking: recent crystal structures of moonlighting proteins. Curr Opin Struct Biol 2004; 14: 663-68.

28. Jeffery CJ. An introduction to protein moonlighting. Biochem Soc Trans 2014; 42: 1679-83.

29. Chaput M, Claes V, Portetelle D et al. The neurotrophic factor neuroleukin is $90 \%$ homologous with phosphohexose isomerase. Nature 1988; 332: 454-55.

30. Gurney ME, Apatoff BR, Spear GT et al. Neuroleukin: a lymphokine product of lectin stimulated T cells. Science 1986; 234(4776): $574-81$.

31. Gurney ME, Heinrich SP, Lee MR, Yin H. Molecular cloning and expression of neuroleukin, a neurotrophic factor for spinal and sensory neurons. Science 1986; 234: 566-74.

32. Watanabe, H. Takehana K, Date M, Shinozaki T, Raz A. Tumor Cell Autocrine Motility Factor Is the Neuroleukin/Phosphohexose Isomerase Polypeptide. Cancer Res 1996; 56: 2960-63.

33. Xu W, Seiter K, Feldman E, Ahmed T, Chiao JW. The differentiation and maturation mediator for human myeloid leukemia cells shares homology with neuroleukin or phosphoglucose isomerase. Blood 1996; 87: 4502-06.

34. Jobin PG, Butler GS, Overall CM. New intracellular activities of matrix metalloproteinases shine in the moonlight. Biochim Biophys Acta Mol Cell Res 2017; 1864: 2043-55.

35. Furukawa T, Yoshimura A, Sumizawa T et al. Angiogenic Factor. Nature 1992; 356: 668.

36. Jeffery CJ. Mass spectrometry and the search for moonlighting protein. Mass Spectrom Rev 2005; 24: 772-82.

37. Soker S, Takashima S, Miao HQ, Neufeld G, Klagsbrun M. Neuropilin-1 Is Expressed by Endothelial and Tumor Cells as an Isoform-Specific Receptor for Vascular Endothelial Growth Factor. Cell 1998; 92: 735-45.

38. Meyer-Siegler K, Mauro DJ, Seal G, Wurzer J, deRiel JK, Sirover MA. A human nuclear uracil DNA glycosylase is the $37-\mathrm{kDa}$ subunit of glyceraldehyde-3-phosphate dehydrogenase. Proc Natl Acad Sci USA 1991; 88: 8460-64.

39. Kato H, Fukuda T, Parkison C, McPhie P, Cheng SY. Cytosolic thyroid hormone binding protein is a monomer of pyruvate kinase. Proc Natl Acad Sci USA 1989; 86: 7861-65.

40. Kennedy MC, Mende-Mueller L, Blondin GA, Beinert $H$. Purification and characterization of cytosolic aconitase from beef liver and its relationship to the iron-responsive element binding protein. Proc Natl Acad Sci U S A 1992; 89: 11730-34. 
41. Ehinger S, Schubert WD, Bergmann S, Hammerschmidt S, Heinz DW. Plasmin(ogen)-binding alphaenolase from Streptococcus pneumoniae: crystal structure and evaluation of plasmin(ogen)binding sites. J Mol Biol 2004; 343: 997-1005.

42. Zhou H, Zhang L, Vartuli RL, Ford HL, Zhao R. The Eya phosphatase: Its unique role in cancer. Int J Biochem Cell Biol 2018; 96: 165-70.

43. Basilion JP, Rouault TA, Massinople CM, Klausner RD, Burgess $\mathrm{WH}$. The iron-responsive element-binding protein: localization of the RNA-binding site to the aconitase active-site cleft. Proc Natl Acad Sci USA 1994; 91: 574-78.

44. Jeffery CJ. Protein species and moonlighting proteins: Very small changes in a protein's covalent structure can change its biochemical function. J Proteomics 2016; 134: 19-24.

45. Jeffery CJ. Moonlighting proteins: complications and implications for proteomics research. Drug Discov Today: Targets 2004; 3: 71-78.

46. Sirover MA. On the functional diversity of glyceraldehyde-3phosphate dehydrogenase: biochemical mechanisms and regulatory control. Biochim Biophys Acta 2011; 1810: 741-51.

47. Jeffery CJ. Proteins with Neomorphic Moonlighting Functions in Disease. IUBMB Life 2011; 63: 489-94.

48. Orosz F, Oláh J, Ovádi J. Triosephosphate isomerase deficiency: facts and doubts. IUBMB Life. 2006; 58: 703-15.

49. Mazzola JL, Sirover MA. Alteration of intracellular structure and function of glyceraldehyde-3-phosphate dehydrogenase: a common phenotype of neurodegenerative disorders? Neurotoxicology 2002; 23: 603-09.

50. Chuang DM, Hough C, Senatorov VV. Glyceraldehyde-3phosphate dehydrogenase, apoptosis, and neurodegenerative diseases. Annu Rev Pharmacol Toxicol 2005; 45: 269-90.

51. Liz MA, Mar FM, Franquinho F, Sousa MM. Aboard transthyretin: from transport to cleavage. IUBMB Life 2010; 62: 429-35.

52. Sekijima Y, Kelly JW, Ikeda S. Pathogenesis of and therapeutic strategies to ameliorate the transthyretin amyloidoses. Curr Pharm Des 2008; 14: 3219-30.

53. Babady NE, Pang YP, Elpeleg O, Isaya G. Cryptic proteolytic activity of dihydrolipoamide dehydrogenase. Proc Natl Acad Sci U S A 2007; 104: 6158-63.

54. Molavi G, Samadi N, Hosseingholi EZ. The roles of moonlight ribosomal proteins in the development of human cancers. J Cell Physiol 2019; 234: 8327-41.

55. Whitesell L and Lindquist SL. HSP90 and the chaperoning of cancer. Nat Rev Cancer 2005; 5: 761-72.
56. Min KW, Lee SH, Baek SJ. Moonlighting proteins in cancer. Cancer Lett 2016; 370: 108-16.

57. Song $X$, Wang $X$, Zhuo $W$, et al. The regulatory mechanism of extracellular Hsp90\{alpha\} on matrix metalloproteinase-2 processing and tumor angiogenesis. J Biol Chem 2010; 285: 40039-49.

58. Hance MW, Dole K, Gopal U et al. Secreted Hsp90 is a novel regulator of the epithelial to mesenchymal transition (EMT) in prostate cancer. J Biol Chem 2012; 287: 37732-44.

59. Díaz-Ramos A, Roig-Borrellas A, García-Melero A, LópezAlemany R. a-Enolase, a multifunctional protein: its role on pathophysiological situations. J Biomed Biotechnol 2012; 2012: 156795.

60. Hara MR, Thomas B, Cascio MB et al. Neuroprotection by pharmacologic blockade of the GAPDH death cascade. Proc Natl Acad Sci USA 2006; 103: 3887-89.

61. Daddacha W, Koyen AE, Bastien AJ, Head PE, Dhere VR, Nabeta GN. SAMHD1 Promotes DNA End Resection to Facilitate DNA Repair by Homologous Recombination. Cell Rep 2017; 20: 192135.

62. Broadley SA, Vanags D, Williams B et al. Results of a phase lla clinical trial of an anti-inflammatory molecule, chaperonin 10, in multiple sclerosis. Mult Scler 2009; 15: 329-36.

63. Vanags D, Williams B, Johnson B et al. Therapeutic efficacy and safety of chaperonin 10 in patients with rheumatoid arthritis: a double-blind randomised trial. Lancet 2006; 368: 855-63.

64. Williams B, Vanags D, Hall S et al. Efficacy and safety of chaperonin 10 in patients with moderate to severe plaque psoriasis: evidence of utility beyond a single indication. Arch Dermatol 2008; 144: 683-85.

65. Yang J, Chen Z, Liu N, Chen Y. Ribosomal protein L10 in mitochondria serves as a regulator for ROS level in pancreatic cancer cells. Redox Biol 2018; 19: 158-65.

66. Hernández S, Ferragut G, Amela I et al. MultitaskProtDB: a database of multitasking proteins. Nucleic Acids Res 2014; 42: 517-20.

67. Chapple CE, Robisson B, Spinelli L, Guien C, Becker E, Brun C. Extreme multifunctional proteins identified from a human protein interaction network. Nat Commun 2015; 6: 7412.

68. Prieto $C$ and Javier De Las Rivas J. APID: Agile Protein Interaction Data Analyzer. Nucleic Acids Res 2006; 34: 298-302. 